\title{
RESPON PERTUMBUHAN DAN PRODUKSI BAWANG MERAH (Allium cepa L) TERHADAP KONSENTRASI AIR KELAPA DAN MEDIA TANAM SECARA VERTIKULTUR Lokot Ridwan Batubara', Rita Mawarni ${ }^{*}$, Rizky Raka Reyanda Pohan' \\ ${ }^{1}$ Fakultas Pertanian/Agroteknologi, Universitas Asahan, Indonesia \\ *Co-author:ndadita@yahoo.com
}

\section{Article Information}

History:

Received: 23-03-2021

Accepted: $30-04-2021$

\section{Keywords:}

Coconut water Planting medium Shallot

Verticulture system

\section{ABSTRACT}

Abstrak: Penelitian ini dilaksanakan di Lahan percobaan Fakultas Pertanian Universitas Asahan di jalan Jend. Ahmad Yani, Kecamatan Kisaran Timur, Kabupaten Asahan pada bulan Oktober hingga Desember 2020. Tujuan penelitian ini adalah untuk mengetahui respon pertumbuhan dan produksi bawang merah (Allium cepa) terhadap konsentrasi air kelapa dan media tanam dengan teknik vertikultur. Penelitian ini menggunakan rancangan Acak Kelompok (RAK) Faktorial dengan 2 faktor yaitu: (1) Konsentrasi Air Kelapa (K) terdiri dari 3 taraf: K1 $=25 \%$ (250 $\mathrm{ml}$ air kelapa $+750 \mathrm{ml}$ air), $\mathrm{K} 2=50 \%$ (500 ml air kelapa $+500 \mathrm{ml}$ air), K3 = 75\% (750 ml air kelapa + $250 \mathrm{ml}$ air) dan (2) Media tanaman (M) terdiri dari 3 taraf: M1 = Tanah + Pupuk kandang sapi (1:1), M2 = Tanah + Pupuk kandang sapi (2:1), M3 = Tanah + Pupuk kandang sapi (3:1). Peubah amatan yang diamati adalah tinggi tanaman, jumlah daun, jumlah umbi per rumpun, berat umbi. Hasil penelitian menunjukkan bahwa konsentrasi air kelapa memberikan pengaruh nyata pada pengamatan jumlah umbi per rumpun dan berat basah umbi, tetapi tidak berpengaruh nyata pada pengamatan tinggi tanaman dan jumlah daun, perlakuan terbaik pada K3 $=75 \%$ (750 $\mathrm{ml}$ air kelapa $+250 \mathrm{ml}$ air). Pada media tanam tidak memberikan pengaruh nyata pada pengamatan tinggi tanaman, jumlah daun, jumlah umbi per rumpun dan berat basah umbi. Interaksi antara konsentrasi air kelapa dan media tanam tidak memberikan pengaruh nyata pada semua peubah amatan

Abstract: : The study was conducted at experimantal field at Faculty of Agriculture, Asahan University, Asahan Regency on October 2020 until December 2020. The study aims to the find out the growth response and production of shallots (Allium cepa L.) to the concentration of coconut water and growth media veticulture. This study used randomized complete block design with two factors: (1) Concentration of coconut water $(K)$ with 3 levels: $K 1=25 \%(250 \mathrm{ml}$ coconut water $+750 \mathrm{~m} /$ water $), K 2=50 \%(500 \mathrm{~m} /$ coconut water $+500 \mathrm{~m} /$ water $), K 3=75 \%$ $(750 \mathrm{~m} /$ coconut water $+250 \mathrm{~m} /$ water) and (2) growth media $(M)$ with 3 levels: $M 1=$ soil + cow manure (1:1), M2 = soil + cow manure (2:1), M3 = soil + cow manure (3:1). Observation parameters were plant height, number of leave, number of bulbs, bulbs weight. The results showed that coconut water concentration had a significant effect on the number of tubers per clump and tuber wet weight, but had no significant effect on observations. plant height and number of leaves, the best treatment at $K 3=75 \%(750 \mathrm{~m} /$ coconut water $+250 \mathrm{ml}$ water). The planting medium did not significantly affect the observations of plant height, number of leaves, number of tubers per clump and wet weight of tubers. The interaction between the concentration of coconut water and growing media did not have a significant effect on all observed variables. 


\section{A. LATAR BELAKANG}

Bawang merah adalah komoditas hortikultura yang sangat berperan penting bagi kebutuhan masyarakat. Tanaman yang digunakan umbinya ini dimanfaatkan sebagai bumbu dapur dan pengobatan. Kebutuhan akan bawang merah ini terus meningkat seiring bertambahnya jumlah penduduk Indonesia. Menurut data (BPS, 2020) produksi bawang merah di Indonesia mengalami peningkatan dalam tiga tahun belakangan ini. Pada tahun 2017 produksi sebesar 1.470.155 ton, pada tahun 2018 sebesar 1.503.348 ton dan pada tahun 2019 produksi mencapai 1.580 .247 ton.

Pada umumnya budidaya tanaman bawang merah masih ditanam di lahan pertanian, sehubungan dengan luas lahan pertanian semakin kecil, sedangkan minat petani cukup besar. Oleh karena itu dalam mendukung ketahanan pangan, perlu dilakukan budidaya bawang merah secara vertikultur. Selain itu tanaman hias berpotensi untuk dikembangkan sebagai usaha agribisnis yang menjanjikan karena permintaan akan tanaman hias terus meningkat dan pasarnya tidak pernah jenuh.

Budidaya bawang merah dengan teknik vertikultur dibutuhkan media tanam tepat yaitu campuran tanah dengan pupuk kandang. Pencampuran media ini dilakukan untuk memperbaiki struktur dan tekstur tanah serta menambahkan hara dan bahan organik di dalam tanah. Pupuk kandang memiliki banyak keunggulan diantaranya kandungan nitrogen $(\mathrm{N})$, fospor (P) dan kalium (K) yang cukup tinggi serta mengandung unsur hara yang lengkap (Evanita et al., 2014).

Faktor- faktor yang mempengaruhi pertumbuhan tanaman terdiri dari faktor internal dan faktor eksternal. Faktor internal merupakan faktor yang terdapat pada benih, bibit atau tanaman itu sendiri. Faktor eksternal merupakan faktor yang terdapat di luar benih, bibit atau tanaman, salah satu yang mempengaruhi pertumbuhan yaitu media tanam.

Media tanam yang baik adalah media yang mampu menyediakan air dan unsur hara dalam jumlah cukup bagi pertumbuhan tanaman. Hal ini dapat ditentukan pada tanah dengan tata udara dan air yang baik, mempunyai agregat yang mantap, kemampuan menahan air yang baik dan ruang untuk perakaran yang cukup.

Penggunaan media tanam yang sifatnya menyimpan air lebih banyak akan mengakibatkan akar dan batang bagian bawah bawang merah dapat membusuk dan jenis media tanam yang memiliki sifat kemampuan menahan air rendah akan mengakibatkan media tanam mudah kering dan tanaman akan cepat mati. Media tanam yang baik harus memiliki persyaratanpersyaratan sebagai tempat berpijak tanaman, memiliki kemampuan mengikat air dan menyuplai unsur hara yang dibutuhkan tanaman, mampu mengontrol kelebihan air (drainase) serta memiliki sirkulasi dan ketersediaan udara (aerasi) yang baik, dapat mempertahankan kelembaban di sekitar akar tanaman dan tidak mudah lapuk atau rapuh (Mariana, 2017).

Selain penggunaan campuran media tanam yang tepat, faktor penting yang perlu diperhatikan dalam budidaya tanaman bawang merah adalah zat pengatur tumbuh (ZPT) alami yaitu air kelapa. Air kelapa mengandung hormon auksin, sitokinin, asam amino, vitamin dan mineral. Kandungan ini merupakan komposisi yang dibutuhkan untuk pertumbuhan dan produksi bawang merah (Simangunsong et al., 2017).

Dari hasil penelitian (Sembiring, 2016) menunjukkan bahwa, perendaman umbi pada konsentrasi air kelapa sebanyak $75 \%$ menghasilkan pertumbuhan dan produksi jumlah umbi yang tinggi dibanding konsentrasi 0\%; 25\%; 50\%; dan 100\%.

Hasil penelitian (Metusala, 2012) menunjukkan bahwa air kelapa kaya akan potasium (kalium) hingga $17 \%$, juga mengandung gula antara 1,7 sampai $2,6 \%$ dan protein 0,07 hingga $0,55 \%$. Hasil penelitian lain juga manyatakan bahwa zat pengatur tumbuh dalam air kelapa mampu meningkatkan hasil kedelai hingga $64 \%$ dan kacang tanah hingga $15 \%$.

Aplikasi air kelapa sebagai bahan zat pengatur tumbuh dan bahan organik adalah salah satu cara untuk menggantikan bahan sintetis yang digunakan dalam pembuatan media kultur seperti kinetin. Keunggulan air kelapa juga setara dengan bahan sintetis yang mengandung hormon sitokinin atau sebagai hormon pengganti sitokinin (Tuhuteru et al., 2018). Oleh karena itu peneliti melakukan percobaan menggunakan campuran media tanam dan konsentrasi air kelapa sebagai ZPT alami yang untuk pertumbuhan dan produksi tanaman bawang merah (Allium cepa L) secara vertikultur.

Tujuan penelitian ini adalah Untuk mengetahui respon pertumbuhan dan produksi bawang merah (Allium cepa L) terhadap konsentrasi air kelapa dan media tanam dengan teknik vertikultur.

\section{B. METODE PENELITIAN}

Penelitian ini dilaksanakan di Lahan percobaan Fakultas Pertanian Universitas Asahan di jalan Jend. Ahmad Yani, Kecamatan Kisaran Timur, Kabupaten Asahan. Penelitian dilaksanakan pada bulan Oktober hingga Desember 2020.

Bahan yang digunakan pada penelitian ini adalah benih bawang merah varietas medan, air kelapa, tanah, kompos, pupuk kandang sapi, insektisida Curacron bahan aktif profenfos $500 \mathrm{~g} / \mathrm{liter}$ air.

Alat yang digunakan adalah talang air, bambu, cangkul, gunting, pisau, parang, gergaji, gembor, tali rapiah, kawat, ember, alat tulis, meteran, timbangan analitik, kamera, plang plot dan plang penelitian.

Rancangan yang digunakan pada penelitian ini adalah Rancangan Acak Kelompok (RAK) Faktorial 
dengan dua faktor yaitu: Konsentrasi Air Kelapa (K) yang terdiri dari 3 taraf yaitu: $\mathrm{K} 1=25 \%(250 \mathrm{ml}$ air kelapa $+750 \mathrm{ml}$ air $), \mathrm{K} 2=50 \%(500 \mathrm{ml}$ air kelapa + $500 \mathrm{ml}$ air $), \mathrm{K}_{3}=75 \%$ (750 $\mathrm{ml}$ air kelapa $+250 \mathrm{ml}$ air). Media tanaman (M) yang terdiri dari 3 taraf yaitu: M1 = Tanah + Pupuk kandang sapi (1:1), M2 = Tanah + Pupuk kandang sapi (2:1), M3 = Tanah + Pupuk kandang sapi (3:1).

Jumlah ulangan 3 , tanaman per plot 5 tanaman, tanaman sampel per plot 3 tanaman, total plot penelitian 27 plot, total tanaman sampel 81 tanaman, total tanaman seluruhnya 135 tanaman.

Pembuatan rak vertikultur dilakukan menggunakan bambu yang disusun bertingkat sebanyak 3 tingkat. Wadah yang digunakan untuk media tanam adalah talang air yang telah diberi pembatas. Pembatas ini agar tanah tetap dalam kondisi utuh dan tidak tumpah serta air terjaga dengan baik. Media tanam yang digunakan adalah campuran tanah dan pupuk kandang sapi. Media ini dimasukkan kedalam wadah talang air yang sudah diletakkan pada rak vertikultur. Jumlah campuran tanah dan pupuk kandang sapi diaplikasikan sesuai dengan perlakuan.

Jarak tanam yang digunakan untuk penanaman bawang merah adalah $20 \mathrm{~cm} \times 15 \mathrm{~cm}$. Sebelumnya bibit yang akan digunakan dipotong ujungnya hingga $1 / 3$ bagian, kemudian direndam dengan larutan Dithane M45 selama 2 jam. Setelah itu bibit ditanam dan membumbun $2 / 3$ bagian umbi. Air kelapa dikumpulkan dari penjual santan di pasar, kemudian dimasukkan kedalam jerigen. Pemberian air kelapa disesuaikan dengan masing-masing perlakuan dengan interval pemberian 1 minggu sekali. Umbi bawang merah dipenen setelah berumur 62 hari setalah tanaman dengan kriteria panen yaitu daun telah menguning, leher batang diatas umbi mulai layu dan tanaman rebah lebih dari 60\%.

\section{HASIL DAN PEMBAHASAN}

\section{Tinggi tanaman $(\mathrm{cm})$}

Hasil analisis sidik ragam menunjukkan bahwa aplikasi air kelapa dan media tanam serta interaksi kedua perlakuan menunjukkan tidak adanya pengaruh yang nyata. Hasil uji beda rata-rata aplikasi air kelapa dan media tanam terhadap tinggi tanaman bawang merah dapat dilihat pada Tabel 1.

Tabel 1.

Rataan Tinggi Tanaman

\begin{tabular}{ccccc}
\hline \multirow{2}{*}{$\begin{array}{c}\text { Air } \\
\text { Kelapa }\end{array}$} & \multicolumn{3}{c}{ Media Tanam (M) } & Rataan \\
\cline { 2 - 4 } (K) & M1 & M2 & M3 & \\
\hline $\mathrm{K}_{1}$ & 22,42 & 23,29 & 23,20 & 22,97 \\
$\mathrm{~K}_{2}$ & 23,32 & 23,99 & 23,14 & 23,48 \\
$\mathrm{~K}_{3}$ & 23,51 & 22,04 & 25,58 & 23,71 \\
\hline Rataan & 23,08 & 23,11 & 23,97 & \\
\hline
\end{tabular}

Dari Tabel 1 menunjukkan bahwa aplikasi air kelapa dan media tanam serta interaksi kedua perlakuan tidak memberikan pengaruh nyata pada pengamatan tinggi tanaman umur $6 \mathrm{mst}$, secara visual tinggi tanaman tertinggi pada perlakuan air kelapa terdapat pada $\mathrm{K}_{3}=75 \%(23,71 \mathrm{~cm})$ dan perlakuan media tanam terdapat pada $\mathrm{M}_{3}=$ tanah + pupuk kandang sapi (3:1) yaitu 23,97 cm.

\section{Umur Berbunga (hari)}

Hasil analisis sidik ragam menunjukkan bahwa aplikasi air kelapa dan media tanam serta interaksi kedua perlakuan menunjukkan tidak adanya pengaruh yang nyata pada umur berbunga. Hasil uji beda rata-rata aplikasi air kelapa dan media tanam terhadap umur berbunga bawang merah dapat dilihat pada Tabel 2.

Tabel 2.

Rataan Umur Berbunga

\begin{tabular}{ccccc}
\hline \multirow{2}{*}{$\begin{array}{c}\text { Air } \\
\text { Kelapa }\end{array}$} & \multicolumn{3}{c}{ Media Tanam (M) } & \\
\cline { 2 - 4 }$(\mathbf{K})$ & $\mathbf{M}_{\mathbf{1}}$ & $\mathbf{M}_{\mathbf{2}}$ & $\mathbf{M}_{\mathbf{3}}$ & Rerata \\
\hline $\mathrm{K} 1$ & 12,00 & 12,56 & 13,00 & 12,52 \\
$\mathrm{~K} 2$ & 13,11 & 13,33 & 11,56 & 12,67 \\
K3 & 12,44 & 12,89 & 12,56 & 12,63 \\
\hline Rerata & 12,52 & 12,93 & 12,37 & \\
\hline
\end{tabular}

Dari Tabel 2 menunjukkan bahwa aplikasi air kelapa dan media tanam serta interaksi kedua perlakuan tidak memberikan pengaruh nyata pada pengamatan umur berbunga, secara visual umur berbunga tercepat pada perlakuan air kelapa terdapat pada $\mathrm{K} 1=25 \%(12,52$ hari $)$ dan perlakuan media tanam terdapat pada M2 $=$ tanah + pupuk kandang sapi (3:1) 12,37 helai.

\section{Jumlah Umbi per Rumpun (buah)}

Dari analisis sidik ragam menunjukkan bahwa aplikasi air kelapa memberikan pengaruh yang nyata. Sedangkan pada perlakuan media tanam dan interaksi kedua perlakuan tidak memberikan pengaruh nyata terhadap jumlah umbi per rumpun.

Hasil uji beda rata-rata aplikasi air kelapa dan media tanam terhadap jumlah umbi per rumpun bawang merah dapat dilihat pada Tabel 3 .

Tabel 3.

Rataan Jumlah Umbi per Rumpun.

\begin{tabular}{ccccc}
\hline $\begin{array}{c}\text { Air } \\
\text { Kelapa }\end{array}$ & \multicolumn{3}{c}{ Media Tanam (M) } & Rataa \\
\cline { 2 - 4 } (K) & $\mathbf{M}_{\mathbf{1}}$ & $\mathbf{M}_{\mathbf{2}}$ & $\mathbf{M}_{\mathbf{3}}$ & \\
\hline $\mathrm{K}_{1}$ & 5,44 & 4,00 & 5,67 & $5,04 \mathrm{~b}$ \\
$\mathrm{~K}_{2}$ & 5,89 & 5,11 & 5,67 & $5,56 \mathrm{~b}$ \\
$\mathrm{~K}_{3}$ & 5,00 & 7,00 & 8,11 & $6,70 \mathrm{a}$ \\
\hline Rataan & 5,44 & 5,37 & 6,48 & \\
\hline
\end{tabular}

Dari Tabel 3 menunjukkan bahwa aplikasi air kelapa bepengaruh nyata terhadap jumlah umbi per rumpun, dimana jumlah umbi per rumpun terdapat pada perlakuan $\mathrm{K}_{3}=75 \%$ (6,70 buah), berbeda nyata dengan K2 (5,56 buah), K1 (5,04 buah). Pada perlakuan media tanam tidak memberikan pengaruh nyata, secara visual jumlah umbi per rumpun terbanyak terdapat pada $\mathrm{M}_{3}$ (6,48 buah).

Hubungan jumlah umbi per rumpun dengan aplikasi air kelapa dan media tanam disajikan pada gambar 1 berikut. 


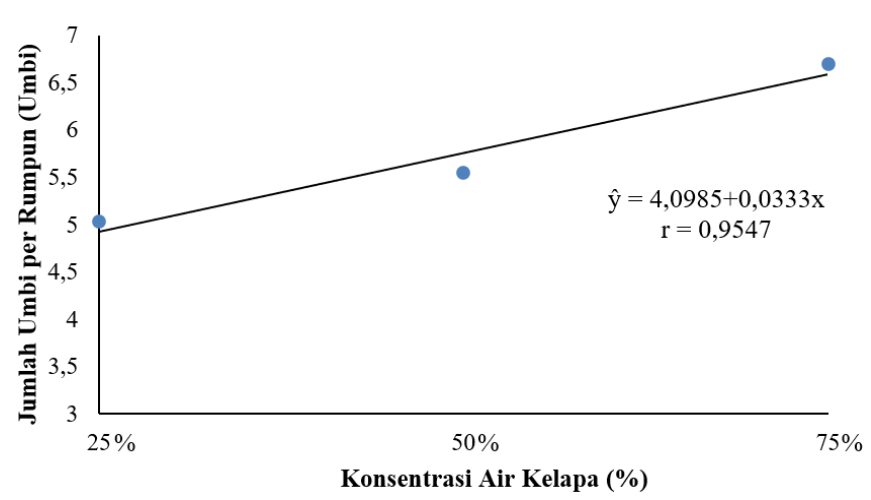

Gambar 1. Hubungan Jumlah umbi per rumpun dengan aplikasi air kelapa dan media tanam

Pada Gambar 1 menunjukkan bahwa jumlah umbi per rumpun mengalami peningkatan seiring dengan bertambahnya konsentrasi air kelapa yang diberikan. Pada grafik terlihat hubungan linier positif dengan persamaan regresi $\hat{y}=4,0985+$ $0,9547 \mathrm{x}$ dan nilai $\mathrm{r}=0,9547$.

\section{Berat Basah Umbi (kg)}

Dari analisis sidik ragam menunjukkan bahwa aplikasi air kelapa memberikan pengaruh yang nyata. Sedangkan pada perlakuan media tanam dan interaksi kedua perlakuan tidak memberikan pengaruh nyata terhadap berat basah umbi.

Hasil uji beda rata-rata aplikasi air kelapa dan media tanam terhadap berat basah umbi bawang merah dapat dilihat pada Tabel 4 .

Tabel 4.

Rataan Berat Basah Umbi.

\begin{tabular}{ccccc}
\hline \multirow{2}{*}{$\begin{array}{c}\text { Air } \\
\text { Kelapa }\end{array}$} & \multicolumn{3}{c}{ Media Tanam (M) } & Rataan \\
\cline { 2 - 4 }$(\mathbf{K})$ & $\mathbf{M}_{\mathbf{1}}$ & $\mathbf{M}_{\mathbf{2}}$ & $\mathbf{M}_{\mathbf{3}}$ & \\
\hline $\mathrm{K}_{1}$ & 50,78 & 44,97 & 40,43 & $45,39 \mathrm{~b}$ \\
$\mathrm{~K}_{2}$ & 48,23 & 43,58 & 45,68 & $45,83 \mathrm{~b}$ \\
$\mathrm{~K}_{3}$ & 47,44 & 52,52 & 53,56 & $51,17 \mathrm{a}$ \\
\hline Rataan & 48,81 & 47,02 & 46,56 & \\
\hline
\end{tabular}

Dari Tabel 4 menunjukkan bahwa aplikasi air kelapa bepengaruh nyata terhadap berat basah umbi, dimana berat basah umbi terberat terdapat pada perlakuan $\mathrm{K}_{3}=75 \%$ (51,17 gr), berbeda nyata dengan K2 (45,83 gr) dan K1 (45,39 gr). Pada perlakuan media tanam tidak memberikan pengaruh nyata, secara visual berat basah umbi terberat terdapat pada M1 (48,81 gr).

Hubungan jumlah umbi per rumpun dengan aplikasi air kelapa dan media tanam disajikan pada gambar 2 berikut ini.

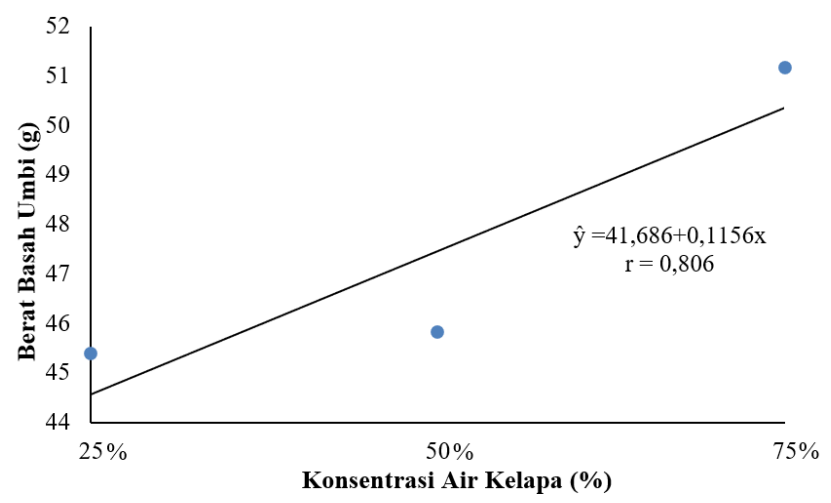

Gambar 2. Hubungan berat basah Umbi dengan aplikasi air kelapa dan media tanam

Pada Gambar 2 menunjukkan berat basah umbi terjadi peningkatan seiring bertambahnya konsentrasi air kelapa yang diberikan. Pada grafik terlihat hubungan linier positif dengan persamaan regresi $\hat{y}=41,686+0,1156 x$ dan nilai $r=0,806$.

Pemberian air kelapa menunjukkan adanya pengaruh nyata pada pengamatan jumlah umbi per rumpun dan berat basah umbi. Sedangkan pada pengamatan tinggi tanaman dan jumlah daun tidak menunjukkan pengaruh yang nyata.

Pengaruh nyata pada pengamatan jumlah umbi per rumpun dan berat basah umbi diduga karena air kelapa mengandung unsur hara dan zat pengatur tumbuh yang dibutuhkan oleh bawang merah dalam mendukung proses metabolisme. Salah satu unsur hara yang terkandung dalam air kelapa adalah nitrogen. Nitrogen berfungsi dalam menyusun asam amino (protein), asam nukleat dan klorofil pada tanaman, sehingga tanaman menjadi lebih hijau, mempercepat pertumbuhan (tinggi, jumlah daun, jumlah anakan) dan meningkatkan produksi umbi) (Putra et al., 2015).

Menurut (Darlina et al., 2016) pertumbuhan yang baik suatu tanaman membutuhkan unsur hara. Jika semua komponen hara dalam keadaan seimbang dan cukup maka proses pembelahan sel akan berlangsung cepat dan pertumbuhan tanaman dapat meningkat. (Kristina \& Syahid, 2012) melaporkan bahwa air kelapa juga mengandung kadar kalium sebanyak 14,11 mg/100 ml, kalsium sebanyak 24,67 $\mathrm{mg} / 100 \mathrm{ml}$, fosfor sebanyak $13,17 \mathrm{mg} / 100 \mathrm{ml}$, dan nitrogen sebanyak 43,00 $\mathrm{mg} / 100 \mathrm{ml}$.

Selain unsur hara, air kelapa juga mengadung hormon yaitu auksin, sitokinin dan giberalin. Kandungan auksin dan sitokinin dalam air kelapa mempunyai peran penting dalam proses pembelahan sel sehingga membantu pembentukan tunas bawang merah (Tiwery, 2014). Auksin mempengaruhi pertambahan bobot umbi karena hormon ini melakukan pembelahan sel yang diikuti dengan pembesaran sel (Nana \& Salamah, 2014). Komposisi media tanam tidak memberikan pengaruh nyata pada semua peubah amatan yaitu tinggi tanaman, 
jumlah daun, jumlah umbi per rumpun dan berat basah umbi bawang merah.

Pengaruh tidak nyata pada media tanam diduga karena komposisi yang digunakan pada media belum cukup tepat untuk dilakukan pada vertikultur. Akan tetapi secara visual terlihat respon yang baik pada tanaman bawang merah.

Media tanam yang berasal dari campuran pupuk kandang sapi dan tanah top soil diharapkan dapat memperbaiki sifat fisik, kimia dan biologi tanah serta mampu membantu pertumbuhan dan produksi umbi bawang merah karena pada pupuk kandang ini terdapat unsur hara yang baik untuk tanaman bawang merah. Pupuk kandang sapi mengandung hara $\mathrm{N}$ 2,33 \%, P2O5 0,61 \%, K2O 1,58 \%, Ca 1,04 \%, Mg 0,33 \%, Mn 179 ppm dan Zn 70,5 ppm (Andayani \& Sarido, 2013).

Hal ini sesuai dengan pendapat (Dinariani et al., 2014) yang menyatakan bahwa pemberian pupuk kandang sapi menyebabkan media tanam lebih gembur dan subur. Tanah yang subur akan mempermudah perkembangan akar tanaman. Akar tanaman yang dapat berkembang dengan baik akan lebih mudah menyerap air dan unsur hara yang tersedia di dalam tanah sehingga dapat tumbuh dan berkembang secara optimal serta menghasilkan produksi yang tinggi.

Berdasarkan analisis sidik ragam dapat diketahui bahwa interaksi antara konsentrasi air kelapa dengan media tanam tidak menunjukkan pengaruh nyata terhadap semua peubah amatan yang diamati. Adanya interaksi kedua perlakuan diharapkan mampu meningkatkan pertumbuhan dan produksi bawang merah dengan kandungan yang terdapat pada air kelapa dan media tanam. Namun dengan tidak adanya interaksi dari kedua faktor ini menunjukkan bahwa pertumbuhan tanaman yang baik dapat dicapai jika faktor yang mempengaruhi seimbang dan saling menguntungkan diantara keduanya.

Tidak adanya hubungan interaksi antara air kelapa dan media tanam yang digunakan, diduga karena adanya perbedaan faktor dari keduanya sehingga tidak saling mempengaruhi. Hal ini sesuai dengan (Soetejo \& Kartasapoetra, 1987), apabila salah satu faktor pengaruhnya lebih kuat dari faktor lainnya maka faktor tersebut akan tertutupi oleh faktor lainnya. Dalam setiap faktor mempunyai sifat yang beda berpengaruh dari sifat kerjanya, maka akan menghasilkan hubungan yang berpengaruh dalam mempengaruhi petumbuhan tanaman.

\section{SIMPULAN}

Konsentrasi air kelapa memberikan pengaruh yang nyata pada pengamatan jumlah umbi per rumpun dan berat basah umbi, tetapi tidak berpengaruh nyata pada pengamatan tinggi tanaman dan jumlah daun. Dimana, perlakuan terbaik adalah perlakuan $\mathrm{K}_{3}$ dengan penggunaan air kelapa sebesar $75 \%$. Selain itu, media tanam dan interaksi antara konsentrasi air kelapa dengan media tanam tidak memberikan pengaruh yang nyata pada pengamatan tinggi tanaman, jumlah daun, jumlah umbi per rumpun dan berat basah umbi.

\section{DAFTAR RUJUKAN}

Andayani, \& Sarido, L. (2013). Uji Empat Jenis Pupuk Kandang Terhadap Pertumbuhan dan Hasil Tanaman Cabai Keriting (Capsicum annum L.). Jurnal AGRIFOR, 12(1).

BPS. (2020). Produksi bawang merah di Indonesia. https://www.bps.go.id/site/resultTab

Darlina, Hasanuddin, \& Rahmatan. (2016). Pengaruh Penyiraman Air Kelapa (Cocos nucifera L.) Terhadap Pertumbuhan Vegetatif Lada (Piper nigrum L.). Jurnal Ilmiah Mahasiswa Pendidikan Biologi, 1(1), 20-28.

Dinariani, Suwasono, \& Bambang. (2014). Kajian penambahan pupuk kandang kambing dan kerapatan tanaman yang berbeda pada pertumbuhan dan hasil tanaman jagung manis (Zea mays saccharata Sturt). Jurnal Produksi Tanaman, 2(2), 27-35.

Evanita, Widaryanto, \& Heddy. (2014). Pengaruh pupuk kandang sapi pada pertumbuhan dan hasil tanaman terong (Solanum melongena L) pada pola tanam tumpangsari dengan rumput gajah (Penisetum purpureum) tanaman pertama. Jurnal Produksi Tanaman, 2(7).

Kristina, \& Syahid. (2012). Pengaruh Air Kelapa terhadap Muliplikasi Tunas In Vitro, Produksi Rimpang, dan Kandungan Xanthorizol Temulawak di Lapangan. Jurnal Littri, 18(3), 125-134.

Lukman. (2019). Teknologi Budidaya Tanaman Sayuran Secara Vertikultur. Balai Penelitian Tanaman Sayuran.

Mariana, M. (2017). Pengaruh Media Tanam Terhadap Pertumbuhan Stek Batang Nilam. Agrica Ekstensia, 11(1), 1-8.

Metusala. (2012). Air Kelapa Pemacu Pertumbuhan dan Pembungaan Anggrek. http://www.anggrek.org/air-kelapa-pemacupertumbuhan-dan-pembungaan-anggrek.html

Nana, \& Salamah. (2014). Pertumbuhan Tanaman Bawang Merah (Allium cepa L.) dengan Penyiraman Air Kelapa (Cocos nucifera L.) Sebagai Sumber Belajar Biologi SMA Kelas XII. JupemasiPbio, 1(1), 82-86.

Putra, Wahyudi, \& Hasanah. (2015). Serapan N (Nitrogen) dan Produksi Bawang Merah (Allium Ascallonicum L) Varietas Lembah Palu Akibat Pemberian Bokashi Titonia (Titonia Diversifolia) pada Entisol Guntarano. Jurnal Agrotekbis, 3(4), 448-454.

Sembiring. (2016). Pengaruh Konsentrasi Air Kelapa Dan Lama Perendaman Umbi Terhadap Pertumbuhan Dan Produksi Bawang Merah Varietas Samosir (Allium ascalonicum L.). Universitas Sumatera Utara, Medan.

Simangunsong, Lahay, \& Barus. (2017). Respon Pertumbuhan dan Poduksi Bawang Merah (Allium ascalonicum L.) pada Konsentrasi Air Kelapa dan 
AGROTEK Jurnal Vol. 8, No.1, 2021/Respon Pertumbuhan dan Produksi Bawang Merah (Allium cepa L) Terhadap Konsentrasi Air Kelapa dan Media Tanam Secara Vertikultur/Lokot Ridwan Batubara, Rita Mawarni, Rizky Raka Reyanda Pohan

Lama Perendaman Umbi. Jurnal Online Agroekoteknologi, 5(1), 17-26.

Soetejo, \& Kartasapoetra. (1987). Pupuk dan Cara Pemupukan. PT Bima Aksara.

Tiwery. (2014). Pengaruh Penggunaan Air Kelapa (Cocos nucifera) Terhadap Pertumbuhan Tanaman Sawi (Brassica juncea L.). Jurnal Biologi, Pendidikan Dan Terapan., 1(1), 86-94.

Tuhuteru, Hehanussa, \& Raharjo. (2018). Pertumbuhan dan perkembangan anggrek Dendrobium anosmum pada media kultur in vitro dengan beberapa konsentrasi air kelapa. Agrologia, 1(1). 